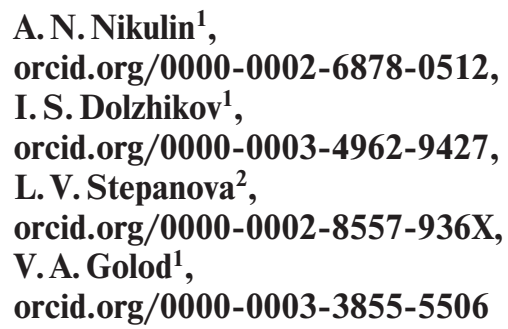

1- Saint Petersburg Mining University, Saint Petersburg, Russian Federation, e-mail: nikulin an@pers.spmi.ru 2 - Peter the Great Saint Petersburg Polytechnic University, Saint Petersburg, Russian Federation

\title{
ASSESSMENT OF NOISE IMPACT ON COAL MINE WORKERS INCLUDING WAY TO/FROM WORKPLACE
}

Purpose. Determination of the noise induced permanent threshold shift for a coal miners in five main working professions, taking into account the noise impact on the way to the workplace and back based on data obtained from personal sound level meters.

Methodology. A strategy is selected for measuring the level of noise exposure at workplaces No. 3 "per workday" (GOST ISO 9612-2016) in a coal mine. Personal sound level meters were attached to the miners' shoulders; they measured the noise level on the way to the workplace, during the work shift ( 8 hours) and on the way back. The processing of the measurement results was carried out on the basis of a quantitative assessment of the noise impact on workers - according to the noise induced permanent threshold shift (NIPTS). The NIPTS values were calculated for a period from 3 to 30 years for 5 main professions, taking into account the noise impact when moving to the workplace and back.

Findings. The values of the equivalent noise level at miners' workplaces of are determined, which are 15 to $20 \mathrm{dBA}$ above the maximum permissible equivalent level ( $80 \mathrm{dBA})$. Based on the results obtained, a constant shift in the hearing threshold was forecast for workers of five occupations with seniority of 3 to 30 years. A reduction in the hearing threshold of a sinker will amount to $25 \mathrm{~dB}$ in 30 years, which corresponds to the occupational disease Stage 3.

Originality. Constant displacement of the hearing threshold for workers in coal mines, caused by the effect of an increased noise level during the journey to the place of work and back, was revealed.

Practical value. It was found that in order to prevent the development of an occupational disease (sensorineural hearing loss) in underground miners, it is necessary to measure the noise level by using personal sound level meters for an 8-hour working day, taking into account the way time to the workplace and back. Noise exposure assessment should be based on a continuous decrease in the hearing threshold.

Keywords: occupational safety and health, threshold shift, coal mine, personal noise dosimeter, noise monitoring

Introduction. Noise is one of the most common harmful factors in the workplaces of coal mining staff [1]. The sources of process noise in mines include nonstop operation of main and local fans, drainage pumping plants, transformer substations and current rectifiers, compressor and refrigerating equipment [2]. A noise level with fans (without air silencers) and turbo-fan plant equipment in operation reaches 100 to $110 \mathrm{~dB}$ [3]. Cutter loaders and tunnelling machines, mechanised complexes, plough installations and scraper equipment, winches, hoists, drill rigs, hand-held drills and other machines generate noncontinuous intermittent noise whose levels frequently exceed standard values in the workplaces and work zones [4].

Long-term exposure of humans to intensive noise (over $80 \mathrm{dBA}$ ) initially results in overall changes and then in partial or complete loss of hearing [5]. Depending on noise duration and intensity, hearing sensitivity decreases to a greater or lesser extent in the form of a temporary noise-induced threshold shift (TNITS), which disappears after noise exposure ceases. While longer and/or greater noise intensity results in the irreversible loss of hearing (auditory inefficiency) characterised by a noise-induced permanent threshold shift (NIPTS) [6].

Currently, noise exposure of mine coal workers is measured based on the results of special workplace condition assessment: it means that a workplace condition class (sub-class) is established based on an equivalent sound level value in the workplace only [7]. However, the following work shift stages are disregarded: descending and ascending in the mine cage, delivery of employees to their workplace at the start and end of the shift in mine transport cars and walking to/from the workplace at the start/end of the shift [8]. A way to/from the workplace may take more than two hours and employees are exposed to various harms and hazards, including an increased noise level [9].

(C) Nikulin A. N., Dolzhikov I. S., Stepanova L. V., Golod V. A., 2021
Literature review. Currently, the Method of Special Labour Conditions Assessment (Order No. 33n of the Ministry of Labour and Social Protection of the Russian Federation dated 24 January 2014) and Characteristics of Special Labour Conditions Assessment in Mining Staff Workplaces (Order No. 996n of the Ministry of Labour and Social Protection of the Russian Federation dated 9 December 2014) disregard noise exposure of coal mine workers on their way to/from their workplace [10] and therefore any additional load on their hearing which results in a greater reduction in the hearing threshold of employees and in occupational diseases [11].

Production noise in the workplaces contributes to faster fatigue which in turn contributes to reduced productivity (Cheremisinoff, N. P., 1996) and increased general and occupational morbidity [12]. A person exposed to intensive noise, on the average, spends 10 to $20 \%$ more physical [13] and psychic efforts to maintain his/her performance achieved at a sound level below $70 \mathrm{dBA}$ [14]. Noise may increase overall morbidity of workers by 10 to $15 \%$ [15]; therefore it is necessary to take into account the full noise load on workers, including that on the way to/from their workplace.

Unsolved aspects of the problem. To date, the noise impact on workers when moving through mine workings to the workplace and back remains insufficiently studied.

Purpose. Assessment of equivalent sound pressure levels at the workplaces of underground personnel of a coal mine including on the way to the workplace and back.

Methods. Noise impact on coal mine workers taking into account the way to/from their workplace was assessed at several stages. The first stage involved the determination of the equivalent sound level in the coal miners' workplace during an eight-hour work shift and, separately, the equivalent sound level on the workers' way to their workplace (descending in and walking across the mine to the workplace) and back (walking from the workplace and being lifted from the mine). Based 
on obtained data, the noise-induced permanent threshold shift during employee exposure to increased noise was calculated at the second stage.

Noise exposure of employees was assessed pursuant to GOST ISO 9612-2016 "Acoustics. Noise measurement for the purpose of evaluating human exposure to noise. Method of measurements at workplaces". Non-continuous noises typical for underground coal mining was then measured by recalculating the averaged energy impact based on time and intensity of permanent exposure [16].

This method includes the following main stages: analysis of the working context, selection of a measurement strategy, measurement, identification of potential errors and assessment of measurement uncertainty, calculations and presentation of measurement results.

Analysis of the working context was performed based on the study on the workflow, analysis of significant noise sources, labour conditions and individual surveys of each employee.

In order to determine a nominal day, including periods at work and employee's way to/from the workplace, the work environment was analysed to identify all factors that may impact noise measurement result in the employee's workplace. The analysis identified:

a) work operations and their variations;

b) main noise sources the employee is exposed to and process areas with increased noise levels;

c) typical structure of the employee's day at work.

The time when an employee started descending into the mine, arrived at the workplace, had breaks during his/her work shift, ended the shift and left the mine was accurately recorded.

The obtained data was used to determine a measurement strategy and measurement plan for each employee.

Noise impact was measured with personal SV 104 noise dosimeters using the selected strategy (Fig. 1). Measurement results were processed in Svantek Supervisor software.

The main quantitative assessment of a noise impact on employees is a noise-induced permanent threshold shift (NIPTS). The median values of NIPTS due to noise depend on the audiometric frequency, duration of impact and level of acoustic impact over a nominal eight-hour workday with a five-day work week and averaged based on exposure duration.

When exposure duration is 10 to 40 years, the median potential NIPTS values $\left(N_{50}\right)$ are calculated according to formula.

$$
N_{50}=\left[u+v \lg \left(\frac{t}{t_{0}}\right)\right]\left(L_{E X, 8 h}-L_{0}\right)^{2},
$$

where $L_{E X, 8 h}$ is a sound impact level over a nominal eight-hour work day expressed in $\mathrm{dB} ; L_{0}$ is a sound pressure level which depends on the frequency below which noise impact on hearing acuity is considered insignificant or negligible; $t$ is exposure duration (expressed in years); $t_{0}=1$ year; $u$ and $v$ are frequency-dependent parameters.

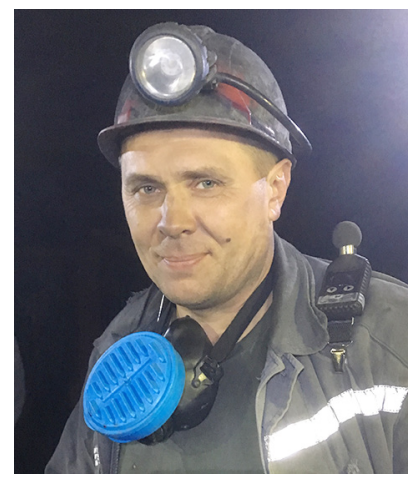

Fig. 1. Attachment of a personal SV 104 noise dosimeter to the employees' special clothes
In order to calculate a NIPTS value with exposure duration of less than ten years, $N_{50}$ value must be extrapolated using $N_{50}$ value for ten years using formula.

$$
N_{50, t<10}=\frac{\lg (t+1)}{\lg (11)} N_{50, t=10} .
$$

In order to take into account the noise impact on employees on their way to/from their workplace (1), apart from a sound impact level over a nominal eight-hour work day $\left(L_{E X, 8 h}\right)$ the value is included of an equivalent noise level the employee is exposed to when descending into the mine and walking to his/her workplace $\left(L_{E X, 1}\right)$ as well as the equivalent noise level the employee is exposed to when walking from the workplace and ascending to the surface $\left(L_{E X, 2}\right)$. NIPTS in employees given their way to/from their workplace and seniority of 10 to 40 years was forecasted according to formula.

$$
N_{50}=\left[u+v \lg \left(\frac{t}{t_{0}}\right)\right]\left(L_{E X, 8 h}+L_{E X, 1}+L_{E X, 2}-L_{0}\right)^{2} .
$$

NIPTS was forecast per employee based on individual measurement results. The obtained data revealed dependencies of a reduced threshold for each of the five selected occupations taking into account noise exposure in the workplace and on the way to/from the workplace.

Results. Equivalent noise level measurements in workplaces and on the way to/from the workplaces were done in a coal mine using the method described above. Noise levels were measured for the occupations that have the greatest noise exposure, including sinker, continuous miner operator (CMO), shearer operator (ShO), longwall miner (LWM), and underground plant operator (UPO). The respondents' age ranged between 23 and 55 years old. The workers were male. A total of 15 workers took part in the survey.

Since the workday of a coal miner is hard to describe, a noise load significantly depends on a work shift and coal mining stage and employees often have to carry out operations with an unknown or unpredictable noise exposure. Measurement strategy 3 was chosen for all employees when a measured value is obtained through continuous noise measurement

This strategy also facilitates checking registration of all noise events as a result of measurements. When checking, the determination of an equivalent sound level over the eight-hour workday or the equivalent sound level over the time the employee spent walking to/from his/her workplace does not require any additional calculations (Fig. 2). On the average, the time spent by the employee to descend into the mine and walk to/from his/her workplace approximates two hours and employees are exposed to variable-intensity industrial noise all the time. The example of the processing of equivalent sound level measurements per employee in Svantek Supervisor is shown in Fig. 2.

The results of equivalent noise level measurements for coal miner during their eight-hour workday (less noise exposure on the way to/from their workplace) are shown in Fig. 3.

Equivalent noise exposures for employees on the way to/ from their workplace were determined separately and summarised in Table.

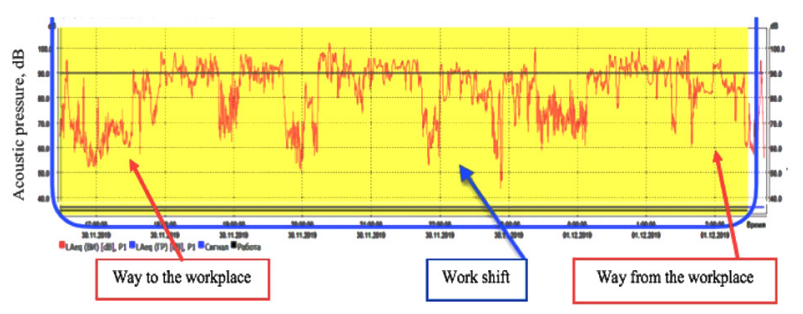

Fig. 2. Example of the processing of equivalent sound level measurements in Svantek Supervisor 


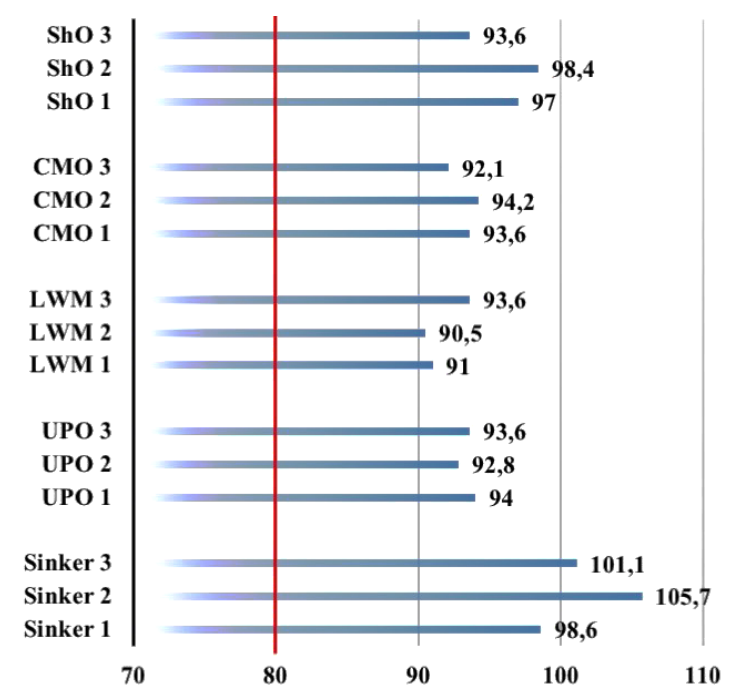

Fig. 3. Equivalent noise level (dBA) over the eight-hour workday

Table

Results of equivalent noise exposure measurements for coal miners on the way to/from their workplace

\begin{tabular}{|c|c|c|c|c|c|}
\hline $\begin{array}{l}\text { Item } \\
\text { No. }\end{array}$ & 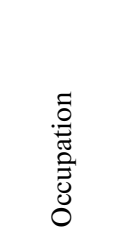 & 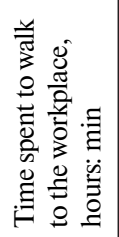 & 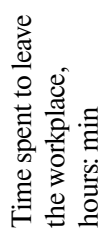 & 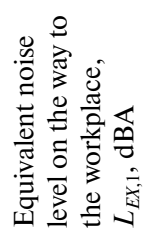 & 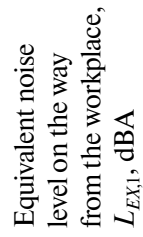 \\
\hline 1 & Sinker 1 & $0: 51$ & 00:55 & 1.95 & 2.325 \\
\hline 2 & Sinker 2 & 01:06 & 01:00 & 2.8375 & 3.2125 \\
\hline 3 & Sinker 3 & 01:00 & $00: 53$ & 2.2625 & 2.6375 \\
\hline 4 & UPO 1 & $00: 43$ & $00: 45$ & 1.375 & 1.75 \\
\hline 5 & UPO 2 & $00: 53$ & $00: 48$ & 1.225 & 1.6 \\
\hline 6 & UPO 3 & 00:44 & $00: 45$ & 1.325 & 1.7 \\
\hline 7 & LWM 1 & 01:06 & 01:02 & 1.0 & 1.375 \\
\hline 8 & LWM 2 & 01:14 & $00: 54$ & 0.9375 & 1.3125 \\
\hline 9 & LWM 3 & 01:13 & $00: 59$ & 1.325 & 1.7 \\
\hline 10 & CMO 1 & 00:54 & $00: 54$ & 1.325 & 1.7 \\
\hline 11 & $\mathrm{CMO} 2$ & 00:57 & 00:50 & 1.4 & 1.775 \\
\hline 12 & $\mathrm{CMO} 3$ & $00: 53$ & $00: 46$ & 1.1375 & 1.5125 \\
\hline 13 & $\mathrm{ShO} 1$ & 01:07 & 01:08 & 1.75 & 2.125 \\
\hline 14 & $\mathrm{ShO} 2$ & 01:04 & 01:06 & 1.925 & 2.3 \\
\hline 15 & $\mathrm{ShO} 3$ & 01:03 & 00:54 & 1.8 & 1.7 \\
\hline
\end{tabular}

The obtained results were used to forecast a noise-induced permanent threshold shift (NIPTS) (1-3) per employee with seniority of three to 30 years; average values were identified per occupation. Results are shown in Figs. 4 to 6.

For the longwall miner and underground plant operator after 30 year of work relationship NIPTS contains 4 and $7 \mathrm{~dB}$. Professional diseases (sensorineural hearing loss) can be realized after $15 \mathrm{~dB}$ [17].

Conclusions. The main research findings are:

1. For a more accurate assessment of the coal miners' exposure to noise, a measurement method based on the use of personal noise dosimeters that enables noise measurement over the work shift must be used.

2. Noise effects on employees must be evaluated using NIPTS forecasting.

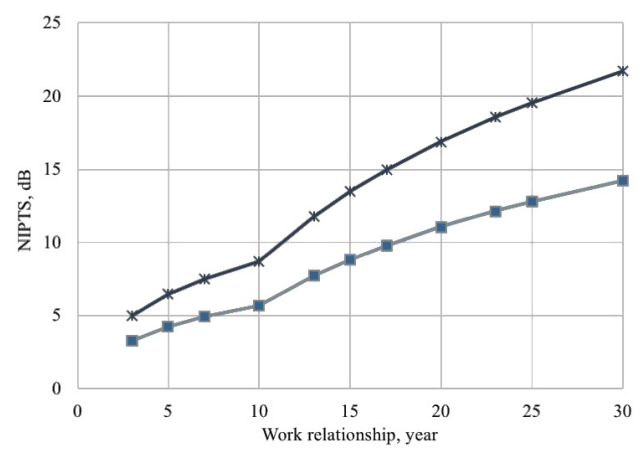

Fig. 4. Shearer operator. Dependence of NIPTS over the working hours on seniority (-) and taking into account time to walk to/from the workplace $(*)$

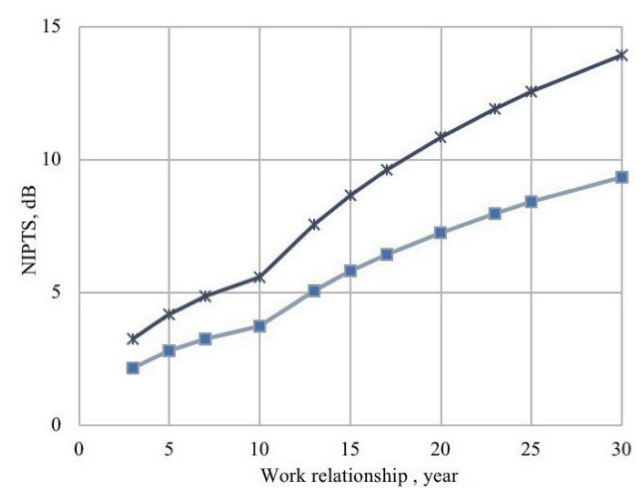

Fig. 5. Continuous miner operator. Dependence of NIPTS over the working hours on seniority (-) and taking into account time to walk to/from the workplace $(*)$

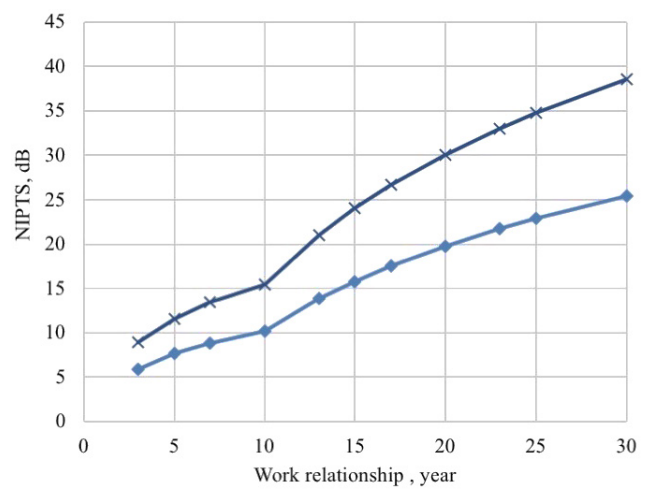

Fig. 6. Sinker. Dependence of NIPTS over the working hours on seniority (-) and taking into account time to walk to/from the workplace $(*)$

3. The coal miners' exposure to noise must be assessed based on NIPTS, including time to/from the workplace.

The first stage of the survey revealed that the equivalent sound level in the coal mining workers' workplaces corresponding to harmful workplace conditions $3.2,3.3$ and 3.4 were significantly exceeded. When using strategy 3 for sound level measurement based on the use of personal noise dosimeters and measurements during a work shift, we received the most accurate noise exposure values for employees of various occupations.

When regulated sound level values are exceeded, employees experience a noise-induced permanent threshold shift. For instance, the medium noise level to whioch longwall miners are exposed is about $92 \mathrm{dBA}$ and a forecasted reduction in the hearing threshold will be 2 and $7 \mathrm{~dB}$ in five and 30 years of work, respectively. The medium noise exposure for a sinker 
exceeds $100 \mathrm{dBA}$, while a forecasted reduction in the hearing threshold will be seven $\mathrm{dB}$ in five years and $25 \mathrm{~dB}$ in 30 years, which corresponds to virtually complete deafness.

Furthermore, underground coal mining implies, apart from actual work in the workplace, spending about two hours to descend into and ascend from the mine in a mine cage, being delivered to the workplace at the start of the shift and back at the end of the shift in mine transport cars, and walking to/ from the workplace at the start/end of the shift while being always exposed to an increased noise level.

Based on the results of the surveys, this exposure may total 1 to $4 \mathrm{dBA}$, which is an additional load on the workers' hearing and during long-term exposure, contributes to a noise-induced permanent threshold shift. For instance, a forecasted noise-induced permanent threshold shift for a sinker with seniority of ten years, given noise exposure in the workplace only, is ten $\mathrm{dB}$, while with exposure to noise in the workplace and on the way to/from the workplace, it will exceed $15 \mathrm{~dB}$. However, with longer seniority, employee exposure to noise on the way to/from the workplace increases.

Acknowledgement. The authors would like to express their gratitude to Ltd "Algorithm-Acoustics" (Moscow, Russia) and head of the company Igor A. Nekrasov for technical support.

\section{References.}

1. Michael, K. L., \& Byrne, D. C. (2000). Industrial noise and conservation of hearing. In R. L. Harris (Ed.), Industrial hygiene ( $5^{\text {th }}$ ed., pp. 15-16). John Wiley \& Sons, Inc.

2. Camargo, H. E., Azman, A. S., \& Peterson, J.S. ( 2018). Engineered noise controls for miner safety and environmental responsibility. In Camargo, H.E., Azman, A.S., \& Peterson, J. S. Advances in productive, safe, and responsible coal mining. Chapter, (pp. 215-243). Elsevier. https://doi.org/10.1016/ B978-0-08-101288-8.00011-0.

3. Ivanov, N., Shashurin, A., Boiko, I., Rudakov, M., \& Tyurina, N. (2017). High-speed train noise source height influence on efficiency of noise barriers. Material of $24^{\text {th }}$ International Congress on sound and vibration, (pp. 123-132). ICSV, London, United Kingdom.

4. Rudakov, M.L. (2016). "Zero accident" corporate programmes as an element of strategic planning in the field of occupational safety and health at coal mining enterprises. Journal of Mining Institute, 240, 465-471. https://doi.org/10.18454/ pmi.2016.3.465.

5. Rudakov, M. L., Kolvakh, K.A., \& Derkach, I.V. (2020). Assessment of environmental and occupational safety in mining industry during underground coal mining, Journal of Environmental Management and Tourism, 11(3), 579-588. https:// doi.org/10.14505/jemt.v11.3(43).10.

6. Chemezov, E. N. (2019). Industrial safety principles in coal mining. Journal of Mining Institute, 240, 649-653. https://doi. org/10.31897/PMI.2019.6.649.

7. Nikulin, A. N., \& Nikulina, A. Yu. (2017). Assessment of occupational health and safety effectiveness at a mining company. Ecology, Environment and Conservation, 23(1), 351-355. 8. Karnachev, I. P., Levashov, S., Shkrabak, R. V., \& Cheltybashev, A.A. (2018). Concept of occupational safety and health management in the Russian industry. Gornyi Zhurnal, 4, 87-92. https://doi.org/10.17580/gzh.2018.04.16.

9. Katuntsov, E. V., Kultan, J., \& Makhovikov, A. B. (2017). Application of electronic learning tools for training of specialists in the field of information technologies for enterprises of mineral resources sector. Journal of Mining Institute, 226, 503-508.

10. Vasilev, Y., Vasileva, P., \& Tsvetkova, A. (2019). International review of public perception of CCS technologies. International Multidisciplinary Scientific GeoConference Surveying Geology and Mining Ecology Management, 19(5.1), 415-422. https://doi.org/10.5593/sgem2019/5.1/S20.052.

11. Kurta, I. V. (2019). Analysis of seismic safety assessment procedures for joint development of coal deposits. IOP Confer- ence Series: Earth and Environmental Science, 378(1). https:// doi.org/10.1088/1755-1315/378/1/012092.

12. Alyanin, A.F., Gallyamov, M.A., \& Abdrakhmanova, E. N. (2019). Industrial noise. Problems and solutions. Oil and Gas Business, 128-142. https://doi.org/10.17122/ogbus-2019-2-128-142.

13. Pathak, R. D. (2001). Industrial noise pollution and conservation of hearing - A study of mine workers. Indian Journal of Otolaryngology and Head \& Neck Surgery, 53(2), 116-22. https://doi.org/10.1007/BF02991503.

14. Eleftheriou, P. C. (2002). Industrial noise and its effects on human hearing. Applied Acoustics, 63(1), 35-42. https://doi. org/10.1016/S0003-682X(01)00022-6.

15. Chui, J., Ma, Y., \& Hertil, S. (2005). Application of barrier in industrial noise control. The Journal of the Acoustical Society of America, 117(4), 2386-2387. https://doi. org/10.1121/1.4785739.

16. Rudakov, M. L., Rabota, E. N., \& Kolvakh, K.A. (2020). Assessment of the individual risk of fatal injury to coal mine workers during collapses. Naukovyi Visnyk Natsionalnoho Hirnychoho Universytetu, (4), 88-93. https://doi.org/10.33271/ nvngu/2020-4/088.

17. Qi, Z. Q., Wang, H., Chang, W., \& Wang, Q. (2017). Analysis for the Influence of Industrial Noise on Brain Cognition of Workers. Dongbei Daxue Xuebao/Journal of Northeastern University, 38(11), 1590-1594. https://doi.org/10.12068/j. issn.1005-3026.2017.11.015.

\section{Оцінка шумового впливу на працівників вугільних шахт з урахуванням проходження на робоче місце та назад}

\section{А. Н. Нікулін ${ }^{1}$, І. С. Должиков ${ }^{1}$, Л. В. Степанова ${ }^{2}$, В. А. Голод ${ }^{1}$}

1 - Санкт-Петербурзький гірничий університет, м. Санкт-Петербург, Російська Федерація, email: nikulin an@pers.spmi.ru

2 - Санкт-Петербурзький політехнічний університет Петра Великого, м. Санкт-Петербург, Російська Федерація

Мета. Визначення прогнозованого постійного зміщення порога чутності для гірників вугільної шахти за п'ятьма основними робітничими професіями з урахуванням шумового впливу за шляхом проходження на робоче місце й назад на підставі даних, отриманих із персональних шумомірів.

Методика. Обрана стратегія вимірювання рівня шумового впливу на робочих місцях № 3 «на основі робочого дня» (ГОСТ ISO 9612-2016) в умовах вугільної шахти. Персональні шумоміри закріплювалися на плече шахтарів і проводили вимірювання рівня шуму за шляхом проходження до робочого місця, протягом робочої зміни (8 годин), і прямування назад. Обробка результатів вимірювань здійснювалася на основі кількісної оцінки шумового впливу на працівників - за постійним зміщення порогу чутності (ПЗПЧ). Розраховані значення ПЗПЧ за період від 3 до 30 років для 5 основних робітничих професій з урахуванням шумового впливу при русі на робоче місце та назад.

Результати. Визначено значення еквівалентного рівня шуму на робочих місцях гірників, що перевищують гранично-допустимий рівень (80 дБА) на 10-25 дБА. На основі отриманих результатів був спрогнозований постійний зсув порогу чутності для працівників 5 професій при стажі роботи від 3 до 30 років. Встановлено, що для прохідника за 30 років стажу зниження порогу чутності складе 25 дБ, що відповідає 3 стадії професійного захворювання.

Наукова новизна. Виявлено постійне змішення порогу чутності у працівників вугільних шахт, зумовлених 
впливом підвищеного рівня шуму під час проходження до місця виконання робіт і назад.

Практична значимість. Встановлено, що для профілактики розвитку професійного захворювання (нейросенсорна туговухість) у підземних гірників необхідно проводити вимірювання рівня шуму шляхом застосування персональних шумомірів за 8-годинний робочий день з урахуванням часу проходження на робоче місце й назад. Оцінку шумового впливу слід проводити за постійного зниження порогу чутності.

Ключові слова: охорона праці, вугільна шахта, персональний шумомір, моніторинг шуму

\section{Оценка шумового воздействия на работников угольных шахт с учетом следования на рабочее место и обратно}

\section{А. Н. Никулин ${ }^{1}$, И. С. Должсиков ${ }^{1}$, Л. В. Степанова ${ }^{2}$, В. А. Голод ${ }^{1}$}

1 - Санкт-Петербургский горный университет, г. СанктПетербург, Российская Федерация, email: nikulin_an@pers. spmi.ru

2 - Санкт-Петербургский политехнический университет Петра Великого, г. Санкт-Петербург, Российская Федерация

Цель. Определение прогнозируемого постоянного смещения порога слышимости для горнорабочих угольной шахты по пяти основным рабочим профессиям с учетом шумового воздействия по пути следования на рабочее место и обратно на основании данных, полученных с персональных шумомеров.

Методика. Выбрана стратегия измерения уровня шумового воздействия на рабочих местах № 3 «на основе рабочего дня» (ГОСТ ISO 9612-2016) в условиях угольной шахты. Персональные шумомеры закреплялись на плече шахтеров и производили измерения уровня шума по пути следования до рабочего места, в течение рабочей смены (8 часов), и следования обратно. Обработка результатов измерений осуществлялась на основе количественной оценки шумового воздействия на работников - по постоянному смещению порога слышимости (ПСПС). Рассчитаны значения ПСПС за период от 3 до 30 лет для 5 основных рабочих профессий с учетом шумового воздействия при движении на рабочее место и обратно.

Результаты. Определены значения эквивалентного уровня шума на рабочих местах горнорабочих, которые превышают предельно-допустимый уровень (80 дБА) на 10-25 дБА. На основе полученных результатов было спрогнозировано постоянное смещение порога слышимости для работников 5 профессий при стаже работы от 3 до 30 лет. Установлено, что для проходчика за 30 лет стажа снижение порога слышимости составит 25 дБ, что соответствует 3 стадии профессионального заболевания.

Научная новизна. Выявлено постоянное смещение порога слышимости у работников угольных шахт, обусловленное воздействием повышенного уровня шума во время следования до места выполнения работ и обратно.

Практическая значимость. Установлено, что для профилактики развития профессионального заболевания (нейросенсорная тугоухость) у подземных горнорабочих необходимо проводить измерение уровня шума путем применения персональных шумомеров за 8-часовой рабочий день с учетом времени следования на рабочее место и обратно. Оценку шумового воздействия следует проводить по постоянному снижению порога слышимости.

Ключевые слова: охрана труда, смещение порога слышимости, угольная шахта, персональный шумомер, мониторинг шума

Recommended for publication by G. I. Korshunov, Doctor of Technical Sciences. The manuscript was submitted 26.12.20. 